\title{
Pediatric nurse's work process: a reality to be transformed
}

\author{
Processo de trabalho do enfermeiro pediatra: uma realidade a ser transformada
}

Tânia Maria Coelho Leite, Maria Silvia Teixeira Giacomasso Vergílio², Eliete Maria Silva²

Objective: to analyze the work process of the pediatric nurse, focusing on the hospitalized child. Methods: this is a qualitative research with 17 nurses of a university public hospital, performed by semi-structured interview and participant observation. The analysis of the data content was based on the referential of the work process in health. Results: the actions of the pediatric nurse indicate that their work is far from the planning of integral and humanized care for the children. It is developed from the biomedical model, predominating technical activities, subordinated to the medical work. The systematization of nursing care is incomplete, and humanizing strategies are rarely used. Conclusion: the work process of the pediatric nurse incorporates little strategies that involve children and parents in the treatment. The nurse is not clear about the complexity of her work object, the hospitalized child, to plan comprehensive actions in their entirety.

Descriptors: Pediatric Nursing; Professional Practice; Child, Hospitalized; Working Conditions.

Objetivo: analisar o processo de trabalho do enfermeiro pediatra, com foco na criança hospitalizada. Métodos: pesquisa qualitativa com 17 enfermeiros de hospital público universitário, realizada por entrevista semiestruturada e observação participante. A análise do conteúdo dos dados foi fundamentada no referencial do processo de trabalho em saúde. Resultados: as ações do enfermeiro pediatra apontam que o seu trabalho está distante do planejamento de um cuidado integral e humanizado para as crianças. Desenvolve-se a partir do modelo biomédico, predominando atividades técnicas, subordinadas ao trabalho médico. A Sistematização da Assistência de Enfermagem é incompleta e raramente utilizam-se estratégias humanizadoras. Conclusão: o processo de trabalho do enfermeiro pediatra pouco incorpora estratégias que envolvam crianças e pais no tratamento. 0 enfermeiro não tem clareza da complexidade do seu objeto de trabalho, a criança hospitalizada, para planejar ações abrangentes à sua integralidade.

Descritores: Enfermagem Pediátrica; Prática Profissional; Criança Hospitalizada; Condições de Trabalho.

${ }^{1}$ Colégio Técnico de Campinas, Universidade Estadual de Campinas. Campinas, SP, Brazil.

${ }^{2}$ Faculdade de Enfermagem, Universidade Estadual de Campinas. Campinas, SP, Brazil.

Corresponding author: Tânia Maria Coelho Leite

Rua Pedro Vieira da Silva, 415, Bloco I, apto. 21. Jardim Santa Genebra - CEP: 13080-570. Campinas, SP, Brazil. E-mail: tania@cotuca. unicamp.br 


\section{Introduction}

Hospitalization in childhood has many implications for those involved in this process: the child, his family, and the entire health team, especially the nursing. The hospitalized child may present feelings of fear, abandonment, and guilt, which can lead to depressive, aggressive behaviors and act with little collaboration, hindering the nursing interventions. Therefore, the work process of these professionals should be geared towards meeting the needs of the child and his/her family. This brings challenges in the organization and working conditions, and the institutional and managerial models of the institution must be considered and analyzed. In this way, understanding the dynamics of health work in the research institution and the participation of nursing in these models are of paramount importance to contributing to a more humanized care.

Therefore, it is necessary to understand the elements that constitute the work process in health, that is, the work object of the team characterized by the user's needs, which can be individual or collective, as well as the appropriate instruments for the development of the work, such as materials, equipment, structured knowledge, and interpersonal relationships, seeking to achieve the purpose of their work, which justifies their existence ${ }^{(1)}$.

The health work is different from other work processes in the service area because it is consumed immediately at the time it is produced. It aims to supply a good or value that involves the quality of life of human beings. In this way, its realization consists of actions that are complex and multidimensional totalities. Its agents do not operate in isolation, but collectively with other health professionals, with their specificities in knowledge and practices that complement each other. It is important to have clarity of the work object, its characteristics, and needs since such knowledge and domains will decisively influence the definition of the actions and how they will be carried out to achieve their goals ${ }^{(2)}$.

In the pediatric area, nursing professionals have a limited understanding of the work process and, often, because they do not identify their work object, they lose the objective of their purpose, failing to plan actions with a broader and humanized hospitalized child $^{(3)}$.

It is necessary to highlight the difficulty of children in experiencing a hospitalization, being away from loved ones, being subjected to painful procedures, among other concerns. Signs such as apathy, irritability, sorrow and crying in the context of hospitalization are indicative of the need for shelter and security, and they are often neglected by the nursing team $^{(4-5)}$. Equally important is the need for the institution to adopt a policy that provides conditions for the development of assistance and management models of excellence, encouraging practices and attitudes in the humanizing perspective.

Historically, the biomedical model in the child care has prevailed focusing on the diseases and their treatment. Since the eighteenth century, with the industrial revolution and the institutionalization of the hospital as a therapeutic place, the emphasis was placed on the recovery of the sick body, being common the isolation of the child and the separation of the parents. The emotional, subjective and social dimensions were not appreciated until the mid-twentieth century when the knowledge of the human and social sciences began to point out the harm that this practice entailed in hospitalized children ${ }^{(6)}$.

The publication of the Platt Report in 1959, which dealt with child hospitalization and pointed out strategies for overcoming child care difficulties, started a new way of thinking about child care. Also, meeting the needs of the child according to its stage of growth and development, and the rights guaranteed by the Child and Adolescent Statute, in 1990, to the permanence of a parent or caregiver, brought a new Childcare. In this way, both the object of the work and its purpose were expanded, and the family and quality 
of life in the care should also be included, significantly modifying the work process of the pediatrician nur$\operatorname{se}^{(7)}$.

Since the beginning of the $21^{\text {st }}$ century, atraumatic care has been advocated in child care, which is in line with the guidelines of the National Humanization Policy of the Brazilian Ministry of Health ${ }^{(8)}$. In this context, the literature has shown the need for the introduction of play strategies and therapeutic toys, which help pediatric nurses in the care work process. Such strategies are important allies at the time of explanation, awareness, and collaboration in the therapeutic procedures necessary for the hospitalized child ${ }^{(4-5,7-9)}$.

Nevertheless, we have not observed the use of these resources as instruments in the work of the pediatric nurse in our daily life. There is a shift in focus from the needs of the child (the object of work) to other demands, which motivated them to understand them and to develop this study. Thus, the objective of this study was to analyze the work process of the pediatric nurses, focusing on the hospitalized child.

\section{Methods}

This is a qualitative study, performed in a large university hospital in the interior of the state of São Paulo/Brazil, with 403 beds. The pediatric admission unit had 58 beds, distributed in four units. Unit 2 and 4 , with 18 beds each, were chosen for the accomplishment of this research because they are similar in physical structure and characteristics to a unit of general hospitalization in pediatrics.

The data were collected from January to June 2011 with the nurses working in these two units, except one woman who was on maternity leave. Therefore, 17 nurses participated, including the unit's nursing managers.

Data collection was performed through semi-structured interviews and participant observation. The interviews were performed in a reserved room, in the pediatric hospitalization unit and previously combined. Names of toys and children's games were used as codenames.

The triggering question was: Tell me about your activities in an ordinary day of work at the pediatric inpatient unit. The interviews were recorded and transcribed in full. Participant observations were performed in the morning, afternoon and evening shifts. The nurses were accompanied by their actions and interactions with the child, with other employees and professionals, technical and administrative activities, following a previously elaborated script. Technical procedures and labor instruments established verbal behaviors and attitudes toward the child, and his or her companion, guidelines, use of play strategies and therapeutic toys; physical conditions of the child and intercurrences were observed. Immediately after each observation period, the description of the activities observed was recorded, as well as the records of their perceptions.

The empirical material produced was organized and analyzed according to the recommendations of the content analysis ${ }^{(10)}$, that is, a reading of the material was extracted by extracting significant parts of the objective. Next, the nuclei were defined for content comprehension and, afterward, the results were treated to interpret and understand the relevance of the data based on the theoretical reference of the health work process ${ }^{(1)}$.

The coded material was presented and discussed in the Group of Studies and Research in Education and Practices of Nursing and Health - the State University of Campinas to increase the reliability of these analyses. Five meetings were held for this purpose, with 10 researchers participating on average.

The study complied with the formal requirements contained in the national and international regulatory standards for research involving human beings.

\section{Results}

Out of the 17 nurses interviewed, 15 were female, with ages ranging from 24 to 52 years old and 
time of operation in this hospitalization unit ranging from three months to 23 years. None of them reported having specialization in pediatric nursing. However, two of the three master nurses developed their studies in the pediatric area.

The following categories were elaborated to understand the central theme, the work process of the pediatric nurse and his object of work: Child, family, and institutional needs; Practices and relationships present at work; Prescriptions and interactions in the health care of the child.

In the category of the needs of the child, the family and institutional needs, the object, cut from reality, was now evidenced as the needs of the child and family, and other needs present in the work process.

It was observed that the nurse provides the care to the child because it is considered essential to their performance, to meet the unavailability of another professional or even to expedite the service. However, the needs met are related only to the routines of the child's hospitalization and his illness. The needs inherent to human development were neither quoted nor observed. I take the exam. Not only difficult access, for example, but the employee is also busy with something else ... I go there, and I take it (Amarelinha).

The nurse performs, directly or indirectly activities linked to care. The professionals reported and, it was also observed, that the nurse spends significant time in low complexity technical activities. It is the professional who does not take the prescription the moment he has to take, the nurse leaves here and goes to take it... the technician refuses to take the exam, the nurse leaves and will take the exam... then, these things happen here and, they do not happen sporadically, they always happen (Ciranda).

Also, there are activities that are private to the nurse, such as the Systematization of Nursing Care, guidelines for nursing technicians and/or for children and mothers, care for serious patients and also with central catheters and probes, besides specific techniques and health surveillance. For this, they need to take the time to accomplish them that he often refers to not having.
The organization, the operation and the dynamics of the work depend on the whole team. The nurses felt overwhelmed and frustrated with the various activities they undertake, such as going after materials that are missing or out of place and they do not perform activities that are exclusively within their competence.

It was observed, and it was also reported that the nurse solves unexpected problems of the infirmary, which are not always part of their assignments, giving conditions for the work processes of other professionals to be performed. ...We have to go after the maintenance service (laughs) ... drag bed, look for chair, litter for Examination (Passing ring)... then we have to take care of the technical staff, the residents, the teachers, the request of the Intensive Care Unit, the Emergency room... and, often, we leave evolution... which is a Nurse's job... (Queimada).

The managers stated that the staff was adequately estimated to attend to the needs of the child and his family, but the lack of commitment of employees who are missing, due to health problems or even without justification, disorganize the process of care work, which is one of the reasons pointed out by nurses for not performing Nursing Care Systematization. ...In a few days, the nursing process and the evolution are not performed, because the team is overloaded, so we give care to the patient, and the task of the nurse ends up leaving... in the background. Sometimes there is more than one fault... then there are six patients for each technician, and it is overloading... we are helping... evolution... we could take it easy, make a history of the patient ... one thing more complete, we end up leaving in the background and doing... the basics (Queimada).

In the category, Practices, and relationships present in work, the differentiated actions of the nurse and the agents involved in the work process were analyzed. It was evident that they originate from two distinct areas: focused on medical diagnosis and therapy, and focused on nursing care.

It was observed that the nurse often neglects the care of the child by valuing medical work more than his own, first supplying the needs of that professional to the detriment of the needs of the child and 
his family, which, in this case, are not evidenced as objects of the nurses' work. The medical staff asks a lot... they want an exam ... we take the exam... then a new examination comes up... you need to punch the child again... (Queimada). If we pick up the hospital gauge, the throughput is extremely high. What does this mean, that we change the child of bed all the time and then the professional pushes the crib, pushes the bed, things break... the reason is more medical than related to nursing, is much more medical. He is the owner of the bed! ... (Ciranda).

The nurses pointed out that doctors are slow in releasing the prescriptions of the day and request transfer of bed for children frequently, to adapt to a need and dynamics of their work, remembering that it is a teaching institution. This is pointed out as a factor that significantly interferes in the development of nursing team activities. Also, it became evident that nursing work is essential to organize medical work, even if this shifts the focus from its work object. ...Because the visits pass late, the prescriptions are late... It is at the end of the shift that comes more hospitalization, then has discharge, has hospitalization... then, it kind of... there are days that is almost noon and a half... and there were some that arrived now little, at noon and forty, noon and forty-five (Casinha).

Nurses' knowledge, so important in the development of their actions, is sometimes devalued by professionals themselves, who fail to carry out important steps in the Systematization of Nursing Care, in detriment of other activities. After that, we try to evolve ... because in that period you have ... you have to run after the tent [of 02] that is not here... sometimes, it does not always have... humidifier does not always have... you have to run after the bottle because you did not come ... you know, you are running after... silly. ...you cannot always evolve and prescribe... not always (Pula-pula).

In this perspective, care actions of humanization such as attention, touch, listening to children and companions, playing and therapeutic toys, among others, are left aside and are not considered essential nor used as a tool for work by the team of nursing.

In addition to the own nurses, technicians and nursing assistants, and the medical team, there is a multi-professional group composed of physiotherapists, social workers, pedagogues, occupational ther- apists, as well as cleaning, laundering, among others, that are directly or indirectly involved in the care of the child and influence their demands, positively or not, in the nurses' work. ...Phone ...ultrasound calling... $x$-ray calling, chaperone asking for a cup, diaper, soap... residents who prescribe during the afternoon... and they will communicate... check the diet list... For example, I am on the phone; I have to stop to check if everything is there, the companions... the diets... (Cabra-cega).

The lack of communication between the medical and nursing staff was pointed out as a difficult aspect in the nurses' work process since it is necessary to check the information several times at the on call because they are not communicated to the nursing team. In several situations, this information is transmitted to the nursing team by the family caregiver member or even by the child. In the middle, we have a lot to go after the resident... a lot. Because the child arrived that they called... hospitalization arrived that nobody informed... their communication is very bad. They talk to the mother they took the oxygen.... We have to go back to see who turned it off... what time they turned it off... because in our report... in the prescription ... we are checking that the child is with oxygen... (Desenho).

In the category, Prescriptions, and interactions in the healthcare of the child, it is clear that there are two focuses on the purpose of the work of the nurse: sometimes focusing on the medical procedure to which the child has to submit (more often), sometimes in the needs of this child, not always effectively involving the family in care. The nurse's job was focused on compliance with the medical prescription. The child is seen as a human being without the ability to understand and have difficulty communicating. First, if you talk to the mother, try to calm the child down... that depends on the procedure, right? So, if you talk... if you tell mom what is going to be done, because usually the kids who are hospitalized with us, they do not understand... (Pega-pega).

In this case, the professional believes that to be possible to perform the medical procedure, it is necessary to use force, the participation of others and even threaten the child. ...You have to wrap him in the sheet; you have to call, sometimes, three people to hold the child... (Queimada).

Also, the nurses pointed out that the lack of in- 
volvement of the whole team in the organization and care of the materials generates discomfort and an increase in the time spent performing several activities, but they did not show solutions to the problem....People do not have much involvement... well, you know... we did not have a multi-parameter monitor, you know... now we have three, sometimes up to four that we can, and people do not beware. The cables... let it all break.... One cable is screwed with a cable from the other; then you pull, everything falls... there you go to organize... then you lose time... (Pula-pula).

It was also evident the nurse's frustration at not having adequate performance to the purpose of his work. Because we work so hard, we ... learn ... to do quality work ... and then, by the time we see it; you cannot implement it. Even the Systematization of Nursing Assistance that we... do a Systematization of Nursing Care very elaborated in the undergraduate learned so much... the time that you will put into practice ...you do not have time ... so this is kind of bad (Amarelinha).

However, there are professionals who are also attentive to the needs of the child, as well as the humanization of care, child development, and non-traumatic hospitalization. The statements and situations observed show the search for alternatives to circumvent the refusal situation to perform the procedure. ...First, you have to try to convince this child... to see if there is even this need, for example, if you lost a vein... will you continue with this antibiotic? (Pula-pula).

These professionals try to establish a bond with the child only to perform the procedure and, in these cases, they use playful resources, performing the procedure with the toys, offering the material that will be used in the procedure, or explaining through drawings where what will be done. This use of playful resources does not necessarily imply the use of the therapeutic toy, the technique of which most nurses refer to not knowing. ...If I have to do a puncture and the child already knows that I am going to do the puncture and she starts to get irritated, I try to play, I try to give those little serynges... and there are children that as soon as you give them, she begins to fondle and even lets puncture (Casinha).

Although the therapeutic toy does not appear as a daily strategy in nursing work, some nurses have shown belief in its effectiveness and have become available to develop it in their practice, although they did not do it regularly.

\section{Discussion}

The data evidenced that, in the routine work of the nurse, there is a predominance of technical activities with an overload of bureaucratic work to the detriment of private activities that are not valued. The literature points out that nurses' work must be focused on the management of care in the planning of all the resources and instruments necessary to provide qualified, humane and safe care ${ }^{(2,11)}$.

The practice of nursing should be oriented towards the promotion of human well-being, considering the body and mind, emphasizing that states of humor can become or aggravate health problems. Thus, the nursing team should not be restricted to performing techniques, but to use alternative resources that lead to the recovery of health and not only to care for the disease ${ }^{(12)}$.

Nursing managers were also impotent and frustrated with the issue of care planning, as they ranged from established norms and routines and from the lack of governance for some decisions such as hiring or firing professionals who were not appropriate for the care of the child and who were not committed to the job; or even to buy materials and equipment, such as toys and games.

Health team actions that could be shared were dependent, and some subordinate to the medical power of nursing work. The nurses referred to idealize their work based on their academic training. However, they are unable to modify it due to the culture established in the institution centered on the biomedical care model.

In this way, the assistance of the hospitalized child is centered on a work fragmented by the multi-professional team that performs technical activities with a reductionist view of the integrality of the child. A study that discusses the autonomy of the 
nurse in the care process corroborates this perspective, revealing uncritical and passive acting, restricting the nursing knowledge and performance, without the recognition of the human being as a complex agent, which is part of a sociocultural environment, with needs and particularities ${ }^{(13)}$.

The lack of time and staff is pointed out by the nurses as justification for the continuity of this care model, but it could be mitigated if there was a participatory and systematized planning of the activities of each professional in the work process, providing the most effective realization of what they consider to be their attribution.

Although the object of nursing work is characterized by the care of human beings and that, for this, it is necessary to appropriate the different knowledge, including the human and social sciences, in addition to the biological field, both professional practice and production of knowledge and the training of nurses have been strongly influenced by positivist science and biomedicine. The nurse in his work has difficulty in opposing the hegemonic model and overcoming it by organizing the doing with innovative instruments and practices ${ }^{(2)}$.

The characteristic of health work is to be collective, the work of one professional influencing the work of the other ${ }^{(1)}$. However, the results showed that the work of the nurse is confused with those of other professionals, and their duties are not well defined in work. Practice, which is appropriate for the current model.

In the logic of the humanization of care, there is a need for reflection by the subjects involved in the work process to a greater understanding of the object and purposes of the work, reorienting the nursing doing with focus on the needs of hospitalized children and families, as well as better time planning for its execution.

The fact that they report a lack of time for activities such as the Systematization of Nursing Care and the therapeutic toy demonstrates how this professional prioritizes the technical and administrative activities to the detriment of actions that can enhance the humanization and qualify the assistance.

Another important fact evidenced in the empirical data is the difficulty of the nurses in identifying their object of work. Studies performed in hospitalized child care units show similar results, such as an unplanned nursing practice, providing momentary demands and focused on medical practice procedures; a Systematization of Nursing Care is not carried out in an integral way; besides the lack of control of the work process by nursing workers; and the non-identification of the work object and the instruments used to transform the object by the nurse $\mathrm{e}^{(3-4)}$.

In several situations, nurses reported and were also observed to perceive the child's manifestations of tension, such as irritability, sorrow or crying and, because of lack of time or unpreparedness to deal with this situation with humanizing strategies, they focused their attention on the recovery of biological health. It is noticed that, in the work process of the pediatric nurse, there is little space for love, affection, touch and playfulness, although these professionals become sensitized to the suffering of the child and the mother when they are in their shoes. Humanization of care actions, such as play and therapeutic toys, are neglected, as they have also been reported in other studies on this theme ${ }^{(4,9,14)}$. It is believed that if the work process is modified by focusing on the child and his family, these techniques will be part of the care routine. To corroborate this assertion, the international literature points to evidence that the application of passive distraction techniques such as television and music use, as well as the active ones through games, are opportunities for professionals to involve children and parents in the treatment, reducing the stress of painful procedures and improving the adverse outcomes of hospitalization ${ }^{(15)}$.

It should be considered that expanded, humanized and comprehensive care depends on radical changes in ways of thinking and attention to hospitalized children and their families, especially in a teaching setting such as a university hospital. The insertion 
of the family in this context is indispensable for the consolidation of a singular and integral therapeutic project in which the construction of subjects is valued $^{(16)}$. This includes the workers, who need to see as transforming subjects of their doing.

The literature shows that child health care is in the process of being built, in a movement that includes the paradigm shift from the disease-centered model and the isolated child to a network construction model, for the inclusion of the family as a partner in the search for integral care ${ }^{(17)}$. There are gaps and limits in child care, to be worked on in organizational and administrative relationships, in strengthening state and municipal public policies, in the work process model and the continuing process of health education ${ }^{(16)}$.

In this sense, producing comprehensive care for the hospitalized child requires a relationship of trust and partnerships between child, family, and nursing. Thus, the singularities of each one, as well as their care needs, need to be identified and adequate, constantly, because this relation is not static. Effective communication is fundamental to incorporate new elements into care and modify previous processes, reorganizing them to new constructions for more effective and adequate care ${ }^{(14,16-17)}$.

The study's limitation is the fact that it was carried out in a single university hospital, with peculiar characteristics.

\section{Conclusion}

The work process of the pediatric nurse is based on an institutionalized routine, currently focused on the biomedical model of caring. The nurses do not demonstrate the clarity of their work object, that is, of the needs of the hospitalized child and, in the day-to-day researches, dedicating to them in a limited way. Thus, the difficulties perceived and reported by nurses related to human, material, structural, communication and power relationships have justified the absence of humanizing actions and unique planning in the care of hospitalized children and their families. Therefore, the work process of the pediatric nurse is configured as a reality to be rethought and transformed.

\section{Collaborations}

Leite TMC contributed to the design of the work, collecting, analyzing and interpreting the data, and writing the article. Vergílio MSTG contributed to the analysis and interpretation of the data, and article writing. Silva EM contributed to the relevant critical review of the content and approval of the final version to be published.

\section{References}

1. Mendes-Gonçalves RB. Práticas de saúde: processos de trabalho e necessidades. São Paulo: CEFOR; 1992.

2. Pires D. Transformações necessárias para o avanço da enfermagem como ciência do cuidar. Rev Bras Enferm. 2013; 66(esp):39-44.

3. Yamamoto DM, Oliveira BRG, Vieira CS, Collet N. 0 processo de trabalho dos enfermeiros em unidades de alojamento conjunto pediátrico de instituições hospitalares públicas de ensino do Paraná. Texto Contexto Enferm. 2009; 18(2):224-32.

4. Oliveira CS, Maia EBS, Borba RIH, Ribeiro CA. Brinquedo Terapêutico na assistência à criança: percepção de enfermeiros das unidades pediátricas de um hospital universitário. Rev Soc Bras Enferm Ped. 2015; 15(1):21-30.

5. Hockenberry MJ, Wilson D, Winkelstein ML. Fundamentos de enfermagem pediátrica - Wong. Rio de Janeiro: Elsevier; 2011.

6. Araújo JP, Silva RMM, Collet N, Neves ET, Toso BRGO, Viera, CS. História da saúde da criança: conquistas, políticas e perspectivas. Rev Bras Enferm. 2014; 67(6):1000-7.

7. Francischinelli AGB, Almeida FA, Fernandes DMSO. Routine use of therapeutic play in the care of hospitalized children: nurses' perceptions. Acta Paul Enferm. 2012; 25(1):18-23. 
8. Ministério da Saúde (BR). Secretaria de Atenção à Saúde. Departamento de ações programáticas e estratégicas. Atenção hospitalar. Brasília: Ministério da Saúde; 2011.

9. Piva D, Quadri E, Destrebecq AL. Nurse's role in the processes of hospital humanization and procedural pain relief in children. Pediatr Med Chir. 2011; 33(4):160-8.

10. Minayo MCS. O desafio do conhecimento: pesquisa qualitativa em saúde. São Paulo: Hucitec; 2014.

11. Silva MM, Curty BIC, Duarte SCM, Zepeda KGM. Nursing safety management in onco-hematology pediatric wards. Rev Rene. 2014; 15(6):915-24.

12. Miranda A, Contreras S. El cuidado enfermero como problema ético: concepto y principios prácticos aplicados al acto de cuidado. Rev Bras Enferm. 2014; 67(6):873-80.
13. Bueno FMG, Queiroz MS. O enfermeiro e a construção da autonomia profissional no processo de cuidar. Rev Bras Enferm. 2006; 59(2):222-7.

14. Collet N. Sujeitos em interação no cuidado à criança hospitalizada: desafios para a enfermagem pediátrica. Rev Bras Enferm. 2012; 65(1):7-8.

15. Koller D, Goldman RD. Distraction techniques for children undergoing procedures: a critical review of pediatric research. J Pediatr Nurs. 2012; 27 (6): 652-81.

16. Lima AS, Silva VKBA, ColletN, Reichert APS, Oliveira BRG. Relações estabelecidas pelas enfermeiras com a família durante a hospitalização infantil. Texto Contexto Enferm. 2010; 19(4):700- 8.

17. Bell JM. Family nursing is more than family centered care. J Fam Nurs. 2013; 19(4):411-7. 